\title{
SLC7A5 Gene
}

National Cancer Institute

\section{Source}

National Cancer Institute. SLC7A5 Gene. NCI Thesaurus. Code C106588.

This gene plays a role in high-affinity transport of large neutral amino acids. 